\title{
FARMER STRATEGY TOWARDS RISKS IN CHILI AGRIBUSINESS THROUGH INFORMAL PARTNERSHIP IN MAJU DISTRICT SIRAM VILLAGE MALANG REGENCY
}

\author{
Kliwon Hidayat ${ }^{1}$ \\ ${ }^{1}$ Lecturer of Agribusiness and Socio-Economics Department, Faculty of Agriculture, University of \\ Brawijaya, Malang, Indonesia \\ *corresponding author: k.hidayat@ub.ac.id
}

\begin{abstract}
The purposes of this research are to identify chili agribusiness risks in the dryland area of medium-high land and analyze farmer strategy towards chili agribusiness risks. The research is conducted in Maju District Siram Village Malang Regency. Data are collected through interview with Juragan, who is middlemen that has power in influencing local market, and 30 chili farmers who have informal partnership with Juragan. Data in this research are analyzed descriptively and critically. The research results show that chili agribusiness risks that faced by farmers are risk in production, price, finance, and institutional risk. Those risks are related each other. The risks that bring negative impact negatively are production risk due to plant diseases, market due to price volatility, and financial risk as well. Informal partnership with Juragan, intercropping cultivation technique (also called as tumpangsari), and better technology implementation are the strategies that are performed by farmers in facing chili agribusiness risks.
\end{abstract}

Keywords: Agribusiness risks, Strategy, Informal partnership, Chili intercropping

\section{INTRODUCTION}

In Indonesia, chili is one of horticulture commodity which owns main priority to be developed either regionally or nationally, besides onion and orange. Due to this commodity has high economic value and market demand, it affects to the macro economy (inflation). Therefore, chili has very large agribusiness potential to be developed.

Chili crop can be cultivated in high land or low land area, in the wetland or dryland, and even in the yard without much specifics agroclimate requirements. However, chili is commodity which easily changed in its physical appearance due to its limited shelf life, thus it must be consumed when it is still fresh or processed to be many processing products such as chili sauce, condiment (sambal), chili paste, chili powder, dried chili, and instant spices.

Chili pepper or simply called as chili (Capsicum annuum L.) is one of crop commodity with many benefits. Despite this commodity mostly used as spices, it also contains nutrition that necessary for men's health. Chili contains of protein, fat, carbohydrate, calcium $(\mathrm{Ca})$, phosphorous $(\mathrm{P})$, iron $(\mathrm{Fe})$, vitamin $\mathrm{A}$ and $\mathrm{C}$, and also alkaloid compounds such as capsaicin, flavonoid, and essential oil.

Table 1. Nutrition content of chili

\begin{tabular}{|c|c|c|}
\hline No & Nutrition Type & $\begin{array}{l}\text { Nutrition } \\
\text { per } 100 \mathrm{~g}\end{array}$ \\
\hline 1 & Water content $(\%)$ & 90.9 \\
\hline 2 & Calorie (kal) & 31.0 \\
\hline 3 & Protein $(\mathrm{g})$ & 1.0 \\
\hline 4 & Fat $(\mathrm{g})$ & 0.3 \\
\hline 5 & Carbohydrate (g) & 7.3 \\
\hline 6 & Calcium (mg) & 29.0 \\
\hline 7 & Phosphorous (mg) & 24.0 \\
\hline 8 & Iron (mg) & 0.5 \\
\hline 9 & Vitamin A (S1) & 470.0 \\
\hline 10 & Vitamin C(mg) & 18.0 \\
\hline 11 & Vitamin $B_{1}(m g)$ & 0.1 \\
\hline 12 & Food edible $(\%)$ & 85.0 \\
\hline
\end{tabular}


Hortikultura Bulletin, 2004 in Anonymous (2015).

The development of chili agribusiness as one of horticulture commodity aims to improve agriculture production and also to reach strategic goal in agriculture development largely, which is to improve farmer income or welfare, food diversification improvement; value added improvement of product competitiveness in order to anticipate the improvement of horticulture commodity import value and, in contrast, to improve export value.

Although chili has good potential to be developed and has good demand prospect; however, chili cultivation in small scale still facing many high problems or risks (high-risk commodity). Chili agribusiness needs much capitals compared to other horticulture. Problems or risks that faced by farmers are business capital limitation. Besides that, chili agribusiness mostly faces many failure risks. From production technical aspect, the risk is quite high frequency of plant diseases, which causes excessive inorganic fertilizer and chemical pesticide utilization to control plant diseases where it results in unsafe chili product to be consumed. From market or price aspect, farmers mostly faces uncertainty selling price, fluctuated price, possibility of low business margin, weak market access, and inability to meet bank technical requirements.

Many studies about risk towards agribusiness had been conducted. Ratnaningsih (2000) conducted a research about farmer analysis towards garlic agribusiness risks. The research of Renthiandy et al., (2000), Muzdalifah et al., (2012) focused to the rice agribusiness, irrigated, and non irrigated rice agribusiness risks. Hartati (2009) focused to the potato agribusiness risks. Tarigan (2009) conducted research about organic vegetable risks. Ramadhani (2015) conducted research about risks of cabbage, chinese cabbage, and carrot commodity price. Ramadhan (2013) conducted research about bell pepper production risks. Moreover, Saptana et al., (2010) conducted research about risk analysis of chili agribusiness in the wetland area of low land through formal partnership context with PT. Heinz ABC. However, research about farmer strategy towards chili agribusiness risks in dryland of medium-high land still not much studied. As the information, dryland of medium-high land characteristics are different with wetland area of low land. Indeed, the risks that faced by chili farmers in the dryland will be different. Therefore, the research about farmer strategy towards chili agribusiness risks through informal partnership pattern with Juragan (also called as middleman) is interesting to be conducted. Moreover, in this research, the meaning of agribusiness risk was the whole risks of chili agribusiness - production, price or market, financial, and institutional risk.

The research problems are as follow: (1) what are chili agribusiness risks that faced by farmers in the dryland area of medium and high land; (2) how is farmer strategy towards many chili agribusiness risks in the dryland area of medium and high land.

The research objectives following the research problems above are: (1) to identify chili agribusiness risks in the dryland area of medium and high land; and (2) to analyze farmer strategy towards chili agribusiness risks in the dryland area of medium and high land.

\section{RESEARCH METHODS The research location}

This research was conducted in Maju District, Siram Village, Malang Regency with three factors considered. First, this village is medium and high land, which is located at 600-1,200 over the sea level. Second, Maju District, Siram Village is one dryland area of chili producer in Malang Regency. Third, chili agribusiness in this location has informal partnership pattern between chili farmer and Juragan.

Geographically, Siram Village is located in the position of $7^{0} 57^{\prime} .44 .59^{\prime \prime}$ south latitude and $112^{0} 33^{\prime} .06 .77^{\prime}$ "west longitude. This village located about 600-2,494 $\mathrm{m}$ above sea level. While, this village topography, in general, is wavy and small part of it is flat. Based on data from BPS (Central Bureau of Statistics) Malang Regency, rain fall in Siram Village is about 2,100 $\mathrm{mm}$. Largest rain fall occurred on late November to the early December which reaches up to $400,04 \mathrm{~mm}$. In normal condition, rainy season occurred on November to May/June in the next year.

Soil fertility condition in this village mapped into three categories, fertile soil for about 250,000 Hectare, soil with medium fertility is about 150 Hectare, and infertile soil for about 12,350 Hectare. It means that mostly (61\%) agriculture area in this village included into fertile category. However, due to this area included into dryland then water needs 
heavily depends on the rain. By those nature conditions, crops that are mostly cultivated by farmers are corn, chili, peanut, sugarcane, thai pepper or bird's eye pepper, cassava and wood plants (sengon laut [albiza falcataria]/acacia and jabon) (Anonymous, 2015). It presented on Table 2 as below.

Table 2. Main commodity according to the district in siram village, 2015

\begin{tabular}{cll}
\hline No & \multicolumn{1}{c}{ District } & \multicolumn{1}{c}{ Main Commodity } \\
\hline 1. Turi & $\begin{array}{l}\text { Sugarcane, corn, thai pepper, } \\
\text { and ginger } \\
\text { Albiza and jabon tree, chili, } \\
\text { 2. Klampok }\end{array}$ & $\begin{array}{l}\text { and corn } \\
\text { Corn, ginger, thai pepper } \\
\text { Thai pepper, ginger and } \\
\text { 3. Kalangal, sugarcane }\end{array}$ \\
4. Ketoan & $\begin{array}{l}\text { Chili, tomato and vegetables, } \\
\text { ginger, sugarcane } \\
\text { Albiza and jabon, chili, corn }\end{array}$ \\
5. Gudean & Chili, corn, ginger, tomato, \\
6. Krajan & cauliflower, and orange \\
\hline
\end{tabular}

Data Source: Monography of Siram Village, 2015 (analyzed)

The distance from Siram Village to the District Capital is about $10 \mathrm{~km}$ in which it needs about 30 minutes, while the distance from this village to Malang City (Gadang market and Merjosari market) is about $12-15 \mathrm{~km}$ which needs about 35 minutes. Meanwhile, the distance from this village to the new capital regency in Kepanjen is about 30 $\mathrm{km}$ and can be reached about 60 minutes.

Population of Siram Village is 5,674 people (2,914 male and 2.850 female). That population included into 1,493 patriarchs. Population percentage according to the age dominated by people in the age of $21-60$ years old for $76 \%$. This large population in the age of 21-60 years old shows that most of people in Siram Village are in productive age. While, from the education level, $40.02 \%$ of Siram Village people graduated from Elementary School.

\section{Sampling method and the analysis}

In this research location, there are many Juragan (or middlemen) that perform informal partnership with chili farmers. One of Juragan is local people. Juragan selected intentionally with consideration that the Juragan bound with two relationship patterns, business and community member relationship. This relationship is unique due to Juragan must harmonize business and community solidarity values and norms. In this research, local Juragan selected as key informant.

Further, from local Juragan, it was obtained information about farmers who perform partnership with that Juragan. The number of chili farmer as partner of that local Juragan was 50 farmers. Farmer sample taken for 30 respondents randomly from those 50 farmers. With that sample number, it was expected to obtain information about various chili agribusiness risks that faced by farmers and farmer strategy towards chili agribusiness risks.

Primary and secondary data collection technique are conducted by interview, observation, and document collection. In-depth interview was conducted with Juragan as key informant. Data are collected from this interview included farmer's names as Juragan partner, partnership process and mechanism, right and duty of Juragan and farmers (as Juragan partner) in normal and abnormal condition. Interview of chili farmers as respondents is done individually. In this interview, questionnaire is used as guidance in data collection. Besides, direct observation is also part of the collecting data in this study. Observation is conducted directly to the land area of farmer's chili agribusiness. Data collected in this activity include chili cultivation practices from the beginning (seedling process) until its harvest time. Data obtained from this observation are documentation of chili agribusiness in the farmer's land. Secondary data are collected from monograph data of Siram Village in 2015/2016.

Descriptive analysis has been selected to generate information provided from the data obtained. Descriptive analysis used is Interactive Model by Miles and Huberman (1992). In this analysis, data are presented in table, figure and citation, and then analyzed critically. It means that the data described first and then interpreted critically.

\section{RESULTS AND DISCUSSION}

Chili agribusiness is conducted by farmers as the as the influence of nature environment and certain socio-economic. The environment means as the farmer's environment in taking decision to perform chili agribusiness (Nuthall, 2011). Therefore, the nature environment and socio- 
economic of farmers in conducting chili agribusiness are important to be described and discussed.

\section{Characteristics of chili farmer as partner}

Chili farmers who perform informal partnership with local Juragan (also called as middleman) have certain characteristics. Farmer characteristics here are age, education level, owned land area, and cultivated chili variety. Each characteristic will be explained as follows:

Table 3. Composition of Farmer According to Age in Maju District, Siram Village, Malang, Planting Season of

\begin{tabular}{cccc} 
& $2015 / 2016$. & & \\
\hline No & Age (Years) & Number of Farmer (People) & Percentage $(\%)$ \\
\hline 1 & $\leq 30$ & 5 & 16 \\
2 & $31-45$ & 14 & 47 \\
3 & $46-60$ & 9 & 30 \\
4 & $\geq 61$ & 2 & 7 \\
& Total & 30 & 100
\end{tabular}

\section{1) Composition of farmer according to age} Chili farmers who perform partnership with Juragan can be categorized into several levels. However, most of them $(47 \%)$ included into the age of $31-45$ years old and then followed by farmers in the age of 46-60 years old. It is presented on Table 3 below.

Source: Survey primary data, 2016

\section{2) Composition of farmer according to formal} education level

From the aspect of formal education level, most of chili farmers own low formal education. Table 4 presents that 87 percent chili farmers ungraduated and graduated from Elementary School, and only 3 percent chili farmers who experience Senior High School education.

Table 4. Composition of farmer according to formal education level in maju district, siram village, malang, planting season of $2015 / 2016$

\begin{tabular}{|c|c|c|c|}
\hline No & Education Level & $\begin{array}{c}\text { Number of Farmer } \\
\text { (People) }\end{array}$ & Percentage $(\%)$ \\
\hline 1 & Ungraduated of Elementary School & 3 & 10 \\
\hline 2 & Elementary School & 23 & 77 \\
\hline 3 & Junior High School & 3 & 10 \\
\hline 4 & Senior High School & 1 & 3 \\
\hline & Total & 30 & 100 \\
\hline
\end{tabular}

Source: Survey primary data, 2015

Although the chili farmers own low formal education level, they can be viewed as success farmers. It is because they have braveness to manage chili agribusiness that needs more capital for their level as well as higher risk than other crops.

\section{3) Composition of farmer according to agriculture land area}

Land area is one important production factor in agribusiness, including chili agribusiness. Most of chili farmers (73\%) own land area about $0.25-0.50$ hectare and only 13 percent farmers own land area above 1,00 hectare (Table 5). From the data analyzed, the most of chili farmers are small farmers, thus they have limited capital for their chili agribusiness. 
Table 5. Composition of Farmer According to Agriculture Land Area in Maju District, Siram Village, Malang, Planting Season of 2015/2016

\begin{tabular}{cccc}
\hline No & Land Area $\left(\mathrm{m}^{2}\right)$ & $\begin{array}{c}\text { Number of Farmer } \\
(\text { People })\end{array}$ & Percentage $(\%)$ \\
\hline 1 & $2,500-5,000$ & 22 & 73 \\
2 & $5,500-7,500$ & 2 & 7 \\
3 & $7,500-10,000$ & 2 & 7 \\
4 & $\geq 10,000$ & 4 & 13 \\
\hline
\end{tabular}

Source: Survey primary data, 2015

\section{4) Composition of farmer according to cultivated chili variety}

Chili seed is other important factor in the chili agribusiness. It is due to chili seeds quality determines the success of farmer agribusiness. Chili variety that cultivated in Maju District Siram Village presented on Table 6.

Table 6. Composition of farmer according to cultivated chili variety in Maju District Siram Village, Malang, planting season of $2015 / 2016$

\begin{tabular}{llcc}
\hline No & Chili Variety & $\begin{array}{c}\text { Number of Farmer } \\
(\text { People })\end{array}$ & Percentage $(\%)$ \\
\hline 1 & Keisar & 7 & 23.3 \\
2 & Super Hot & 3 & 10.0 \\
3 & Scarlet & 10 & 33.3 \\
4 & Dewa & 6 & 20.0 \\
5 & Gada & 4 & 13.4 \\
\hline
\end{tabular}

Source: Survey primary data, 2015

From Table 6 above, it shows that dominant chili variety that cultivated by chili farmers is scarlet variety (33\%), and Kaisar variety (23\%). Superhot variety is least cultivated by farmers of Juragan partner. Scarlet variety is dominantly cultivated by farmers because this variety is appropriate and suitable with land condition and also has resistance to the plant disease which leads into easy cultivation treatment. In good condition, scarlet variety has potential to produce up to 1.5 $\mathrm{kg} /$ plant.

\section{Partnership relation between juragan and chili farmers}

Juragan (or called as middleman) is one that gives capital loan to the chili farmers, such as seeds, chemical fertilizer and organic fertilizer, chemical pesticide, mulch, and so forth that needed by farmers in their chili agribusiness. Juragan has occupation as intermediary and farmer as well. Juragan stays in the same district to the chili farmers who perform partnership. not only does
Juragan has larger capital than other farmers but also has chili marketing network in Malang or East Java as well as outside of East Java Province.

In the partnership, the duty of chili farmers as the partner is to sell their chili production to Juragan. As the returns, Juragan established chili price IDR 1,000-1,500 per kg lower than market price in the harvest time. If chili price is high, then the difference price that established by Juragan and received by farmers can be more than IDR 1,500 per $\mathrm{kg}$. Besides, farmer's duty as partner is to refund the capital loan to Juragan.

As the information that chili harvest time can be up to 10 times. Harvest time conducted by farmers in each week and chili product weighed and delivered to Juragan. After weighing and selling process, farmers given by the record of their harvest product and price that received by farmers. Due to the price during the harvest times is different, thus price that received by farmers during the harvest times also different. Payment for their chili product performed after the chili harvest done. At that time, it is conducted by calculation of chili

Volume 17, Number 01 (2017): 06-15 
farmer revenue. Net revenue will be given to farmers after it is subtracted by the capital loan. As the conclusion, chili farmers have to wait about 5 months to get their revenue from chili agribusiness.

This partnership relation between Juragan and chili farmer is informal due to this cooperation is not legal and has no written contract, rather than it is conducted over the trust among both parties. Because both parties live in the same district then both of them know each other.

\section{Type of risk in chili agribusiness}

Agribusiness cannot be separated from uncertainty and risks. It is because there are many factors that can affect the success of agribusiness. As we know, not all factors can be controlled by farmers. Agribusiness risk in this research means the chance or opportunity for the damage or bad impact over an action. The higher uncertainty of bad impact, the higher risk that will be suffered by farmers. While, uncertainty means future situation that cannot be predicted certainly.

Agribusiness risks emerge from factors that unable to be predicted and controlled completely by farmers. According to Nuthall (2011), in agribusiness, there are many types of risk and uncertainty such as (1) technical and production uncertainty; (2) price and input factor uncertainty; (3) financial uncertainty; and (4) advanced technology uncertainty.

In this research location, the farmers realize that chili agribusiness is high risk agribusiness. In their opinion, risk that faced by farmers in chili agribusiness is plant disease risk. Chili included into vulnerable to the plant disease. The plant disease heavily related to the local weather condition. Moreover, farmers also face lack of water for irrigation. As mentioned above, dryland chili agribusiness really depends on the rain fall. Although planting season conducted in the rainy season, however, the rain fall cannot be well predicted. In the context of chili agribusiness, water are needed for the crops fertilizing and also for crops disease controll using pesticides. Furthermore, other risk that faced by farmers in Siram Village is chili market and price that will be received by farmers.

Most of chili farmers in this village are small farmers who own land area less than 0.500 hectare (Table 5). They also have limited chili marketing network. Therefore, price is unctrolable and their revenue is difficult to be predicted due to fluctuated price of chili product. The effect is that farmers will face the risk when chili price is low during the harvest time, thus they will be suffered by loss.

According to farmer's opinion, chili agribusiness is included into high capital (financial) agribusiness. Therefore, farmers need capital loan in order to run their chili agribusiness. Capital source can be from formal institution (BRI Bank) or from informal institution (Juragan). For small scale farmers, financial risk heavily related to the production risk and market or chili price risk as well as institutional risk, especially for capital institution. Actually, relatively for a long time, BRI local district Bank has served farmer's financial needs. Scheme for this loan is a credit for business programme (KUR-Kredit Usaha Rakyat) and village business credit (Kupedes-Kredit Usaha Pedesaan). As formal financial institution, farmers that intended to submit capital loan must follow the established formal rules. However, most of farmers prefer to informal credit system due to its flexibility. If farmers need loan, then they can come to Juragan anytime (morning, noon, evening, holiday, and so on) and get the financial support from them much easier than the formal bank, such as BRI.

\section{Farmer strategy towards chili agribusiness risks}

Chili farmers in this study area cannot be categorized as farmer that been described by Scott (1999), which is farmers who avoid risks (risk aversion). They already knew that chili agribusiness is high risk agribusiness and at the same time it is also profitable agribusiness. Therefore, they keep growing chili on their land due the expected profit will be earned. For facing this situation, the farmers have strategies towards those chili agribusiness risks.

The strategy mostly is based on their experience in the chili agribusiness. Some strategies identified towards chili agribusiness risks are as follows: (1) performing partnership relation informally with Juragan; (2) implementing intercropping (tumpangsari) chili agribusiness system with other crops; (3) applying technology (mulch) and completing chili agribusiness supporting facilities. Each of strategy explains as follow. 


\section{Performing informal partnership with juragan \\ The main reason about why chili farmers} performing partnership relation with Juragan is due to capital constraint. Chili Farmers have not enough capital to run their chili agribusiness. To cope with this capital limitation, they perform informal partnership with Juragan. Farmers who perform partnership with Juragan, have benefit in having support in the cost of seeds, chemical fertilizer and organic fertilizer, mulch, water irrigation, and pesticide, which are going to be supplied by Juragan. Thus, farmers do not need to think about those costs. Additionally, the problem faced by farmers in marketing can also be solved because Juragan guarantees to buy the farmers' product. In unwritten partnership rules between farmers and Juragan, indeed, farmers should sell their harvest product to the Juragan. While, price that received by farmers (farmer's revenue) depends on price fluctuation in the market. Juragan will buy farmer's chili product although chili price in the market falls down.

If farmers suffered by loss in chili agribusiness - it might be due to harvest failure or price falls down - then the loan of production facilities (during production process) fully burdened to farmers to pay it back. However, Juragan gives times to farmers as partner in order to pay the loan back in the next planting season. In order to make farmers able to pay their loan, then Juragan is ready to give capital loan for the next chili planting season. It will be different if farmers take capital loan from bank, then farmers must pay their credit back on the time scheduled as the initial agreement. The flexibility of agreement among Juragan and chili farmers is definitely the factor of the farmers choosing the informal loan option.

\section{Implementing intercropping chili agribusiness system with other crops}

If farmers perform partnership with Juragan, then farmers will gain their revenue from chili agribusiness after chili harvest finished. It means that farmers will get their income or revenue from their chili agribusiness after waiting for about 5 months. Thus, from the first to the tenth harvest time, farmers do not get their revenue from chili agribusiness yet. Juragan will pay the money for farmers after the revenue reduced by the amount of loan given to the farmers. If the revenue is less than the amount of the loan; then, the payment should be made for the next season.

In overcoming this risk, the farmers' strategy is implementing intercropping (tumpangsari) system. The contract with Juragan is only chili product, while the other crops will be fully owned and funded by farmers. Therefore, although farmers have to wait the revenue of chili agribusiness for five months, farmers have other income source from other crops. For instance, if intercropping implemented between chili and cauliflower, farmers will gain revenue from this cauliflower when chili crop is in 50 days old. It is due to cauliflower age is about 50 days. There are various intercropping systems between chili and other crops that implemented by farmers. This diversity appears in the variety and number of intercropping crop that cultivated by farmers. It presented on Table 7 below.

From Table 7, it shows that intercropping system as farmer strategy to cope with production risk, price or market rice utilize various crops, such as chili pepper and thai pepper or bird's eye pepper, cauliflower, tomato, eggplant, onion, corn, and orange. This various crops utilized along with chili can be seen from the Table 7. Most of farmers $(46.7 \%)$ are implementing intercropping system between chili and three other crops. Intercropping chili with four other crops is $23.3 \%$ of farmers responden, and the farmers that implement intercropping system between chili and five other crops are $3.3 \%$ of total farmers responden.

Implementing chili intercropping agribusiness with other crops, despite the strategy towards chili agribusiness risks, is also farmer's effort in maximizing land resource utilization. Besides, Siram Village is dryland area, thus water needs for the crops depends on the rain. Rainy season in this area occurred on November to May or June in the next year. Therefore, during the rainy season, farmers attempt to utilize their land as maximum as possible in order to fulfill their life needs.

\section{Applying Technology and Completing Supporting Facilities}

Farmers already realize that chili agribusiness is vulnerable to the crop diseases and weeds. In overcoming those risks, they implemented two strategies: the first is utilizing mulch to each land row of chili in order to eradicate weeds or grass. In the farmers' opinion, mulch application can prevent 
or decrease weed and crop diseases. Therefore, all farmers in Siram Village use mulch to their chili cultivation. The second is controlling crop disease using pesticide (curative). The use of pesticide needs water and it must be available when farmers spraying their chili crops. Rainfall is difficult to be predicted recently; then, the farmers make retention basin (embung) in their land to supply their water needs. As a result, they can overcome the risk of water shortage and the risk of late controlling crop diseases as well as risk of low chili production.

Based on direct observation in the study area, it shows that farmers in Siram Village have implemented land conservation technology. This land conservation technology is certainly needed in the area with slope and wavy topography. The benefit of the conservation applied are to prevent the land from landslide and erosion, which will be occurred, particularly, in the rainy season. Land conservation technology that have been applied are making bench terrace, planting terrace, and planting in the land side. Due to they have applied land conservation technology, then they pay less attention on land slide or erosion risk.

Table 7. Intercropping Variety According to the Crop Type in Maju District, Siram Village, Planting Season of 2015/2016

\begin{tabular}{|c|c|c|}
\hline Intercropping Variety & $\begin{array}{l}\text { Number of } \\
\text { Farmer }\end{array}$ & $\%$ \\
\hline 1. Intercropping system between chili and one other crop & 3 & 10.0 \\
\hline a. Chili + chili pepper & 2 & \\
\hline b. Chili pepper + orange & 1 & \\
\hline 2. Intercropping system between chili and two other crops & 5 & 16.7 \\
\hline a. Chili + chili pepper + cauliflower & 2 & \\
\hline b. Chili + chili pepper + eggplant & 1 & \\
\hline c. Chili + thai pepper + cauliflower & 1 & \\
\hline d. Chili + cauliflower + tomato & 1 & \\
\hline 3. Intercropping system between chili and three other crops & 14 & 46.7 \\
\hline a. Chili + chili pepper + tomato + cauliflower & 5 & \\
\hline b. Chili + chili pepper + thai pepper + cauliflower & 3 & \\
\hline c. Chili + chili pepper + cauliflower + tomato & 2 & \\
\hline d. Chili + chili pepper + thai pepper + tomato & 1 & \\
\hline e. Chili + chili pepper + cauliflower + eggplant & 1 & \\
\hline f. Chili + chili pepper + eggplant + tomato & 1 & \\
\hline g. Chili + thai pepper + eggplant + tomato & 1 & \\
\hline 4. Intercropping system between chili and four other crops & 7 & 23.3 \\
\hline a. Chili + chili pepper + thai pepper + cauliflower + tomato & 2 & \\
\hline b. Chili + chili pepper + thai pepper + cauliflower + eggplant & 2 & \\
\hline c. Chili + chili pepper + thai pepper + cauliflower + onion & 1 & \\
\hline d. Chili + chili pepper + cauliflower + eggplant + tomato & 1 & \\
\hline e. Chili + chili pepper + cauliflower + tomato + corn & 1 & \\
\hline 5. Intercropping system between chili and five other crops & 1 & \\
\hline $\begin{array}{l}\text { a. Chili }+ \text { thai pepper }+ \text { tomato }+ \text { cauliflower }+ \text { eggplant }+ \text { green } \\
\text { chili or jalapeno }\end{array}$ & 1 & 3.3 \\
\hline Total & 30 & 100.0 \\
\hline
\end{tabular}

Source: Survey primary data, 2015 


\section{CONCLUSION AND SUGGESTION}

\section{Conclusion}

Farmers already realized that chili agribusiness in the dryland is high risk agribusiness. The chili agribusiness risks in the dryland of medium-high land consists of production, marketing and price, financial, and institutional risk. Those risks related each other. The risk that dominantly suffered by farmers was production risk due to plant diseases, market, and fluctuated chili price as well as financial risk.

Farmers attempt to use certaint strategy towards There are some benefit obtained by chili farmers through partnership with Juragan. First, the farmers are able to use mulch and to control crop diseases quickly. It is because pesticide costs can be easily obtained from Juragan by which it can avoid production loss. Second, the farmers have flexibility to implement intercropping system with other crops. It can compensate the farmers' losses if there are problem in chili production or price. Third, farmers have certainty in their chili marketing. Fourth, when the harvest failure occurred, the farmers can postpone their credit payment until the next planting season in which farmers still have opportunity to run their chili agribusiness in the next season due to the other availability of capital loan from Juragan. Futhermore, the farmers also have other strategy implemented to overcome production problem related to water shortage by using retention basin. This will give opportunity to the farmers in applying pests and diseases control and fertilizing the crops.

\section{REFERENCES}

Anonim, 2015. Pola Pembiayaan Usaha Kecil dan Menengah: Klaster Cabai Merah Organik. Departemen Pengembangan UMKM, Bank Indonesia, Jakarta.

Hartati,A., 2009. Pengaruh Perilaku Petani Terhadap Risiko Keefisienan Usahatani Kentang di Kabupaten Wonosobo Jawa Tengah. Fakultas Pertanian Universitas Jenderal Sudirman, Purwokerto.

Muzdalifah, Masyhuri, Ani Suryantini, 2012. Pendapatan dan Risiko Pendapatan Usahatani Padi Daerah Irigasi dan Non Irigasi Di Kabupaten Banjar, Kalimantan
Selatan. Jurnal Sosial Ekonomi Pertanian,1 (1): 65-74.

Pasaribu, S.M., 2013. Perlindungan Usahatani Terhadap Risiko Perubahan Iklim. Dalam Haryono Soeparno, Effindi Pasandaran, Muhrizal Syarwani, Ai Dariah, Sahat M.Pasaribu, Nono Sutrisno Saad (Ed.), 2013. Politik Pembangunan Pertanian Menghadapi Perubahan Iklim. Badan Penelitian dan Pengembangan Pertanian, Kementrian Pertanian. IAARD Press.

agribusiness risks in order to reduce thgse loss until minimum level due
www.litbang.pertanian.go.idfbuku/politkpembangunan/

Peter L. Nuthall, P.L., 2011.Farm Business Management Analysis of Farming Systems. CABI North American Office 875 Massachusetts Avenue 7th Floor Cambridge, MA 02139, USA.

Ramadhani, S. 2015. Strategi Petani Dalam Menghadapi Resiko Harga Komoditas Kol, Sawi Putih dan Wortel di Tanah Karo:Studi Kasus: Desa Gurusinga, Kec.Berastagi, Kab. Tanah Karo. Skripsi pada Fakultas Pertanian Universitas Sumatera Utara, Medan

Ramadhan,A., 2013. Analisis Risiko Produksi Cabai Paprika di Kelompok Tani Dewa Family Desa Pasirlangu Kecamatan Cisarua, Kabupaten Bandung. Skripsi pada Skripsi pada Departemen Agribisnis, Fakultas Ekonomi dan Manajemen, IPB, Bogor.

Ratnaningsih, N., 2005. Perilaku Petani Dalam Menghadapi Resiko Pada Usahatani Bawang Putih di Kecamatan Tawangmangu. Jurnal Eksakta, 26(1) : 61-70.

Renthiandy,P.A., J.Sutrisno, M.T.Sundari, 2000. Analisis Risiko Usahatani Padi di Kecamatan Karanganyar, Kabupaten Karanganyar. Fakultas Pertanian Universitas Sebelas Maret, Solo.

Saptana, A.Daryanto, H.K.Daryanto dan Kuntjoro, 2010. Strategi Manajemen Risiko Petani Cabai Merah Pada Lahan Sawah Dataran Rendah di Jawa Tengah.Jurnal Manajemen dan Agribisnis: 7(2) : 115-131.

Tarigan, P.E.S.B., 2009. Analisis Risiko Produksi Sayuran Organik Pada Permata Hati Organik Farm di Bogor Jawa Barat. Skripsi pada 
